Article

\title{
Co-Evolution and Bio-Social Construction: The Kichwa Agroforestry Systems (Chakras) in the Ecuadorian Amazonia
}

\author{
Daniel Coq-Huelva ${ }^{1, *}$, Angie Higuchi ${ }^{2}$ (D), Rafaela Alfalla-Luque ${ }^{3}$ (), Ricardo Burgos-Morán 4 \\ (iD) and Ruth Arias-Gutiérrez 5 \\ 1 Department of Applied Economics II, Universidad de Sevilla, Avda. Ramón y Cajal 1, Sevilla 41005, Spain \\ 2 Department of Business Administration, Universidad del Pacífico, Jesús María 15072, Peru; \\ a.higuchi@up.edu.pe \\ 3 GIDEAO Research Group, Departamento de Economía Financiera y Dirección de Operaciones, \\ Universidad de Sevilla, Avda. Ramón y Cajal 1, Sevilla 41005, Spain; alfalla@us.es \\ 4 Departments of Earth and Life Sciences, Universidad Estatal Amazónica, 160101 Puyo, Ecuador; \\ rburgos@uea.edu.ec \\ 5 School of Environmental Engineering, Universidad Estatal Amazónica, 160101 Puyo, Ecuador; \\ rarias@uea.edu.ec \\ * Correspondence: dcoq@us.es; Tel.: +34-95-455-7648
}

Received: 29 August 2017; Accepted: 18 October 2017; Published: 24 October 2017

\begin{abstract}
Polycultured agrarian systems in Ecuadorian Amazonia (also called chakras or swollen gardens) are characterised by a market-oriented crop for the generation of monetary income, for example, cocoa, other agricultural products (e.g., banana and cassava), and livestock for family farm consumption. Moreover, a chakra is an outstanding example of agroforestry production, in which ecological, social and economic elements co-evolve from a set of close and strong connections. In this context, the conservation and transformation of their biological subsystems can be understood as the result of complex interactions between anthropogenic and non-anthropogenic factors. In turn, such interactions are essential to provide food and monetary income to the indigenous community. Relevant agency capabilities exist that could cause an agroforestry system to take a different path of co-evolution, that is, towards greater or lesser sustainability associated with different levels of complexity. In conclusion, chakras have key ecological features that can mitigate the impact of human population growth in Amazonia. Additionally, chakras have their own processes of social self-regulation which enhance the possibilities of adaptation of Kichwa communities to changing environmental conditions, being essential elements in local food sovereignty, equitable gender relations and the respect of ancestral wisdom.
\end{abstract}

Keywords: ecological economics; agroecology; indigenous knowledge; Sumak Kawsay

\section{Introduction}

\subsection{General Elements}

From an ecological perspective, Amazonia is a strategic region for the entire planet for reasons including the size of the territory, its role as a carbon sink, its capacity for slowing climate change and its great biodiversity [1-3]. However, in general, Amazonia and the Ecuadorian Amazonian Region (EAR) in particular are subject to strong pressures that, in some well-known cases, have promoted the radical transformation of its ecosystems [4]. The majority of such pressures have a strong anthropogenic element and thus cannot be understood without considering a set of associated socio-economic factors $[5,6]$. 
The ensemble of pressures that the EAR undergoes can be grouped into two main categories. On the one hand, natural resources in specific production enclaves are being increasingly exploited, which is mainly associated with oil and mining activities [7-11]. On the other hand, EAR has experienced an intense population growth. One of its origins is the strong migration from other Ecuadorian regions, which accelerated after the land reforms of 1964 and 1973 [12]. In fact, colonisation, land distribution, deforestation and the extension of the agrarian frontier have proceeded in parallel [13]. Moreover, the model of the colonist economy and land use is centred on the development of livestock activities that has relevant environmental effects [4,14].

Another reason for Amazonian population growth has been the natural population development of the indigenous communities [15-17]. Indigenous systems of agrarian production are based on agroforestry farms (chakras or swollen gardens). An understanding of the operation of the indigenous agroforestry systems is essential in the context of rapid deforestation and a potentially high loss of biodiversity [6-20]. In the sense, some of the basic traits of Amazonian ecosystems could be modified as the result of their adaptation to changing socio-environmental conditions [21,22].

The objective of this article is to analyse the Amazon Ecuadorian chakras from a co-evolutionary perspective. Chakras have relevant biological and social features than cannot be understood separately. The concept of co-evolution will be used to approximate the interaction among its main biological and social elements. The focus will be placed on the analysis of the main characteristics of the different subsystems. The connections among its biological and social sub-systems (e.g., knowledge, values, organisation and technology) will be underlined. In such analysis, there is an element of description, which is not secondary, as many of the most important characteristics of the chakras has remained invisible as a consequence of the subaltern positions traditionally undertaken by indigenous peoples in Ecuador [23-26]. Thus, its visibility can promote some degree of empowerment of local communities that, in turn, is an essential feature of any process in sustainable transition [27]. Additionally, the application of the co-evolutionary theoretical framework has a relevant interpretative element. It allows deepening in social cognition and collective learning associated to chakras. Those factors are essential in understanding their adaptive and process oriented character [28]. Chakras can be considered as a conjoining of culturally specific means of bio-social construction and in a case of the practical implementation of locally adapted patterns of sustainable development.

\subsection{Sumak Kawsay, Co-Evolution and Socio-Ecological Construction in Agroforestry Systems}

Agroforestry systems built from indigenous cultural foundations are frequently characterised by strong interactions between their socio-economic and environmental variables [29]. A theoretical framework to approximate such interactions is essential for their analysis [30,31] and is related to the search for patterns of sustainable development and supported by the joint consideration of economic, social and environmental elements [32].

Sustainability is a polysemic concept that has different meanings, considering the diversity of ontological positions and disciplinary traditions [33,34]. Strong sustainability, which is frequently assumed among other alternative definitions, supports that the stock of natural resources, and their ecological associated functions cannot be replaced, neither by alternative forms of capital accumulation nor by other social and economic issues. Therefore, if natural resources are degraded, they cannot be (at least fully) replaced because of the irreversibility of key ecological and economic processes [35,36]. The strong sustainability approach has been translated to more applied terms, developing different theoretical tools such as social metabolism [37], life cycle assessment [38] or ecological footprint [39].

Another concept, closely associated to strong sustainability, is co-evolution. It was born from the field of Ecology, and it refers to interactive change processes between, e.g., butterflies and flowers, parasites and hosts, and predators and prey [40,41]. Norgaard [42-44] was the first author who used the concept to explain the joint evolution of social and environmental factors and their interactions. Indeed, it was a creative application of a concept originally used in biology that challenges one of the basic tenets of Western thinking the dichotomy between nature and society [45]. Co-evolution 
considers society to be moulded by the environmental context in which it is embedded, and the environmental element changes the overall analysis because some of the ecological scales have relevant effects on specific political and economic dynamics [46-48]. Additionally, nature is not considered a "pristine" reality, but a result of a social construction [49].

"Coevolutionary agricultural development has been taken place for millennia. The rise of paddy rice culture in Southeast Asia is an instructive example. The land-extensive practice of slash and burn agriculture was gradually abandoned as investments were made in dikes, terraces, and water delivery systems over a period of centuries. The benefits for the ecological transformation to paddy culture came on the form of superior weed control and greater nutrient retention. The transformation, however, was not unilateral. The social system also evolved in order to maintain the environmental transformation. Social mechanisms reinforcing individual behaviour which supported the environmental transformation was sustained by complex social organization of water management, rights to land, and labour exchanges; the social and environmental systems coevolved together, each reflecting the other. Similarly, new technologies, new values and new ways of knowing were selected in the light of coevolution between the environment and social organization." [50] (pp. 25-26)

Co-evolution focuses on limits of "pristine natural" evolution and processes of strictly social construction, insisting that many environmental transformations cannot be understood in the absence of the social context in which they are promulgated. In addition, a counterargument holds that many social changes can be explained by modifications in the natural base that supports human activity [51,52]. In this context, processes of bio-social construction exist that are characterised by not only human agency but also high uncertainty [53,54], which is associated with complex, fluctuating environmental interactions. Human adaptive processes often imply interactions between, and even modifications of, social and ecological aspects $[47,55,56]$. Nature is considered social because people exert selective pressure on the environment, transforming the biosphere. Society is, in turn, natural because social subsystems are conditioned by the characteristics of their ecosystems. The possibility of the generation, survival and evolution of social subsystems is conditioned by the characteristics of the natural environment [57-60]. Thus, co-evolution supports the idea of dialogue between the social and the natural being associated to uncertainty, non-linearity and complexity of the process of bio-social transformation [61,62]. Agroecological systems have been a privileged context for the application of co-evolutionary approaches [50], being agrarian practices understood as privileged mechanisms of bio-social constructs based on the exploitation and emulation of energy and material cycles.

Those elements are particularly relevant in the Amazon. Although an indigenous population has existed for centuries, Amazonia has been historically considered by different national elites as empty, and thus a "pristine" space $[12,63,64]$. However, the cosmology of the indigenous people did not see the forest as empty, but full of people who inhabit, use and transform it [65]. Because the cosmology of indigenous people can frequently be quite abstruse because it is expressed in a prevalent symbolic language, a step beyond can be taken when a set of postulates logically intertwined among them is built. Theoretical developments generically labelled Sumak Kawsay, or good living in Kichwa have contributed to the development of the logical expression of the main elements of the indigenous cosmological system [66-71].

The point of departure of Sumak Kawsay is the claim that the community (or communitarian) scale prevails. However, the indigenous concept of community is very close to a co-evolutionary approach because it includes not only people but also animals, plants, and ecosystems, as well as forces and spirits who supposedly live in the territory, and all of their interactions [72]. Good living is a question of harmony among all of these elements and cannot be considered independently. Thus, nature and society are not bifurcated; instead, the community is pre-eminently associated with the conservation of the natural environment [73].

In his first works, Noorgaard [42,43] discussed only two subsystems, one social and the other environmental, and the interactions between them. The more elaborate version of Norgaard and 
Sikor [50] identified five subsystems for the application of co-evolution to agrarian systems, i.e., knowledge, values, organisation, technology and biology. In reality, such an approach takes an additional step in the socialisation of the original content of the concept of co-evolution by introducing four different subsystems (i.e., knowledge, values, organisation and technology) in lieu of a single social subsystem. This development contributes to the better identification of the sources of the transformation of agroecological systems as well as the multiplicity of effects acting on them [74,75].

In any case, agroecological and agroforestry system are subject to social and environmental pressures. The concept of co-evolution does not erase the differences among them, but it problematises the chain of effects. Thus, some of these pressures can often be analysed in the original subsystem and even stabilise within it. However, if the perturbations are very intense, some of the patterns of interaction can be radically transformed, so pressures originating in one subsystem can affect the other subsystems. For instance, a strong association is present between the changes in the Amazonian landscape and transformations of the indigenous governance systems, that is, there is a close interaction between changes in biological and social subsystems in a broader context of ever changing agroecological systems [76]. As a result, some changes in the farm biological subsystem could have direct effects on key social issues such as family self-sufficiency, effective levels of monetary income or family reproduction. In addition, some changes in values, knowledge or technology can be associated to productive intensification and modification of the prevailing patterns of environmental management.

In such cases, intense dynamics of subsystems' feedback may occur, generating chaotic and non-linear processes. Some risk exists of the occurrence in the phenomena of collapse or catastrophe, which can be understood as a dramatic and radical reduction of the complexity of the overall system [77]. To avoid this risk, the social systems frequently act as a stabiliser, particularly for values and forms of knowledge $[29,54,78]$. An agroecological system is a complex construct that has a high capacity for absorbing disruption, partially because of the interrelationships among the different subsystems.

From a co-evolutionary perspective, traditional agroecological systems are characterised by strong interactions between their different components, the latter being understood as those characterised by temporal and spatial proximity [79]. It means that, when there are some changes in one subsystem, they tend to be stabilised using resources which are territorially close. When such stabilisation is not possible, there can be induced transformations in different subsystems, but considering spatial proximity of the elements which are used. Consequently, in the chakras' case, the majority of the transformations will be at a farm or communitarian level, because there is not enough monetary income for supporting any form of "ecologies at a distance" [80-82]. Therefore, a strict definition of co-evolution (strong co-evolution) can be applied in this context [83].

\section{Materials and Methods}

From a methodological perspective, this study takes a pluralist approach using different information sources. Specifically, a qualitative-quantitative approach has been implemented. Thus, some quantitative data and also in-depth interviews have been generated and interpreted. Both have been considered as complementary instead of mutually exclusive [84,85].

This article was focused on the analysis of the indigenous agroforestry systems of North Eastern EAR, specifically of the provinces of Napo and Pastaza. However, a set of reducing criteria has been applied. On the one hand, only polyculture farms in Kichwa communities have been analysed. On the other hand, only farms with cocoa as the main commercial crop were analysed. Currently, only two crops can generate the monetary income that is demanded by the indigenous communities: cocoa and coffee. However, coffee cultivation in the provinces of Napo and Pastaza is very low.

The qualitative phase of this study comprised 31 in-depth interviews. As cocoa plays the central role of as the source of monetary income, this paper focused on the analysis of cocoa production and distribution. Seven experts were interviewed from different public institutions that were engaged 
in the promotion of cocoa production. Nurserymen, intermediaries, managers of cooperatives and 17 farmers were also interviewed. Small differences among chakra farmers exist in the EAR, being the farms are relatively homogeneous as far as production is concerned.

Questions about different aspects related to the social construction of the productive activities associated with the different crops that coexist on the farms (e.g., cocoa, banana, cassava, small poultry, and livestock) were posed. There were four main categories. Farm visits were a relevant part of the in-depth interviews and the surveys (25). Some farms were only accessible by foot on narrow paths several kilometres long. The photographs that illustrate this article were made during those visits.

The interviews were transcribed, and the transcripts were analysed. In this process, the identification of categories was particularly relevant. On the one hand, the content analysis of the discourses is associated with a previous systematisation of the topics considered, namely, interpretative categories of analysis were supported by the baseline theoretical framework. On the other hand, categories that came from the interviews, which are the expressions of the dominant cognitive frameworks of the agents, are also included.

The research team also participated in events and meetings about the chakras, cocoa production or public policy planning in Amazonia. For instance, the research group participated in the Table of Cocoa of the provinces of Napo and Pastaza, in workshops included in the agenda for the transformation of Amazonia promoted by the Ministry of the Competitiveness and Productivity (MCPEP is the Spanish acronym) and in workshops about protocols for prior permission to gain access to Amazonian genetic resources that was organised by the German Agency for International Cooperation (GiZ) and the Ministry of Environment in different cities of Ecuador and, particularly in Puyo and Tena, the two main cities of the provinces of Pastaza and Napo.

In the quantitative phase, a questionnaire was developed to generate information about the three main perspectives in which sustainability is understood: economic, social and environmental. This research followed a strong sustainability approach considering that degradation in key natural resources cannot be generally compensated by alternative forms of capital accumulation. Consequently, they were questions about key ecological features of chakras, their capacity for providing family food needs and the workload associated to their operation. Due to the fact that the previous census of producers did not exist and due to high number of indigenous farms, sampling was performed based on convenience in a selected set of communities. The different communities were selected according to the conclusions and recommendations from the qualitative phase. Specifically, 70 farmers in the communities of Bajo Talaj (20) and Shandia (20) in Napo, as well as Arajuno (15) and Canelos (15) in Pastaza were surveyed (see Figure 1).

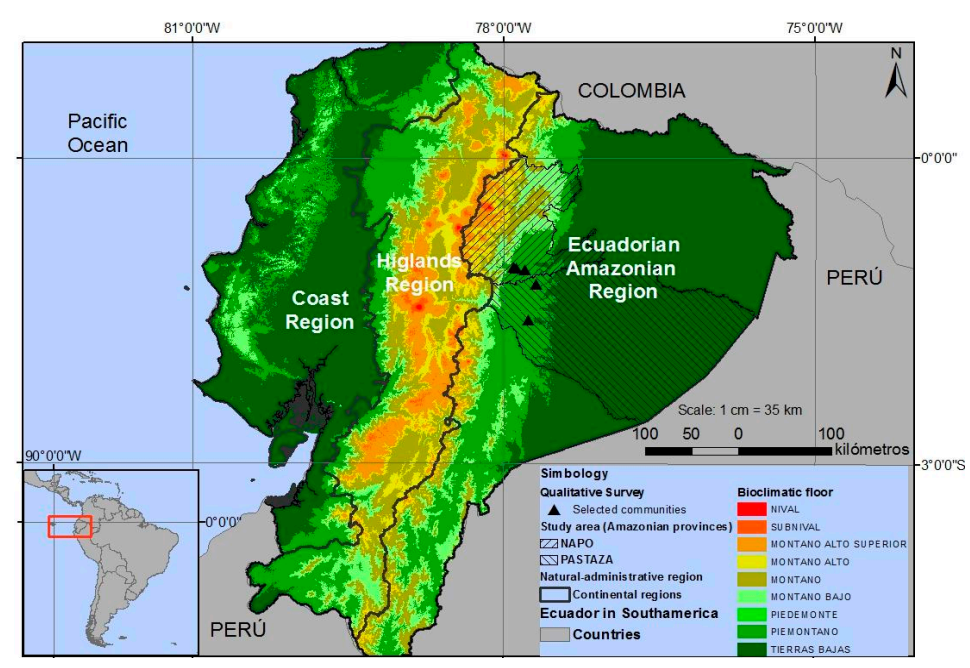

Figure 1. Ecuadorian Amazonia Region and the location of the chakras of the analysed communities. 
The first objective of the questionnaire was to quantify some particularly relevant elements from an agronomic and production perspective (e.g., the size of the farms, the amount of cropped land, the various existing crops). Additionally, the questionnaire sought to approach some of the primary elements that helped to define the chakra as an agroforestry system, such as polyculture, or high biodiversity of plants and animal. However, the most important objective of the questionnaire was to assess the production capability of the chakra from an integrated ecological-economic perspective. Thus, estimates of gross physical (tonnes), economic (dollars), and energetic (kilocalories) production were developed as a result of the information that were obtained, even though some of those topics were not always directly asked.

The chakras in the provinces of Napo and Pastaza have a broad set of common elements, but some aspects vary between the different areas. This article is centred on the elements common to both provinces, which allows the majority of the typical elements of the co-evolutionary model of the chakra (e.g., the forest size, the relevance of polyculture, the low input levels or the work time distribution) to be approached from intuitive and simple statistical indicators (i.e., arithmetic means and frequencies). Despite their simplicity, these indicators provide conclusive evidence, so more complex statistical instruments are not necessary. In this sense, all the tables which are in the epigraph of results have been prepared by the authors based on the results of the project survey.

Notwithstanding, the research team wanted to emphasise one of the primary vectors of the transformation of Amazonian agroforestry systems. They identified a set of variables in the qualitative phase of the analysis for this purpose (e.g., human pressure, farm size, and age of the farmer who was primarily responsible for the farm). In the quantitative phase, the main purpose was to quantify some of the variables which were identified in the previous stage. A rich set of data was obtained that could be exploited using different techniques. A $t$-test was used for analysing patterns of association and possible relations of causation among specific variables. For instance, in this article, a $t$-test was used for analysis if there were substantial differences in key elements of the organisation subsystem (family size, family workload, etc.) according to the age of the principal farmer. This element was important in order to understand the relation between intensification and family reproduction cycles.

\section{Results: The Amazonian Chakra as a Co-Evolutionary Reality}

As mentioned earlier, the concept of co-evolution requires that nature and society cannot be considered independently; rather, it is the mutual feedback among their different parts that is important. In this study, following the approach of Noorgard and Sikor [50], five different subsystems were considered: biological, knowledge, values, organisation and technology.

\subsection{Biological Subsystem}

Because it is an agroforestry system, an essential feature of a chakra is that, frequently, a relevant share of its land is forest. It can be a primary forest undisturbed by man or a secondary forest that has been regenerated after exploitation and simplification because of human activity. Specifically, the average of primary or secondary forest in the farms analysed was slightly greater than $40 \%$ (Table 1 ). The average size of a farm was 16.7 hectares, and 6.8 hectares were given over to the forest. However, substantial differences among the farms were present. More than $25 \%$ had less than $5 \%$ of their land as forest, in contrast to $25 \%$ that had more than $75 \%$ (Survey data).

Table 1. Inclusion of forest in farms' surface (\%).

\begin{tabular}{lcc}
\hline Farms' Surface & Forest Share of Total Land & $\begin{array}{c}\text { Number of Farms } \\
\text { Surveyed }\end{array}$ \\
\hline Less than 5 hectares & 16.1 & 36 \\
From 5 to 15 hectares & 55.2 & 9 \\
More than 15 hectares & 70.9 & 25 \\
Total & 40.4 & 70 \\
\hline
\end{tabular}


Moreover, the farms with a higher share of forest tended to have a bigger size. In this context, the $t$-test for testing the equality of means was highly significant with a $p$-value of 0.000 . Therefore, strong evidence indicates that farm size affects the amount of forest present.

In addition to forest, a chakra is a cropping system with a high level of biodiversity present in its different elements; one of which is the existence of a high number of timber and fruit trees inside of the farm and often outside the forested area. However, it is not possible to approximate their type and number because of the high biodiversity of the Amazonian forest and the fact that many of the species of trees appear in a way that is very discontinuous from a territorial perspective. Table 2 shows some of the tree species existing on the farms.

Table 2. Existence of timber and fruit trees inside the farms (\%).

\begin{tabular}{lcll}
\hline $\begin{array}{l}\text { Main Timber Trees (Spanish or Kichwa } \\
\text { Names) }\end{array}$ & Percent of Farms & Main Fruit Trees (English Name) & $\begin{array}{c}\text { Percent } \\
\text { of Farms }\end{array}$ \\
\hline Chonta (Bactris gasipaes) & 98.6 & Avocado (Persea americana) & Sapote (Pouteria sapote) \\
Canelo (Ocotea spp.) & 52.9 & Tangerine (Citrus nobilis) & 28.6 \\
Chuncho (Cedrelinga caeteniformis) & 57.1 & Lemon (Citrus lemon) & 75.7 \\
Aguano (Swietenia macrophylla) & 48.6 & Grapefruit (Citrus paradisi) & 88.6 \\
Guaba (Inga edulis) & 87.1 & Orange (Citrus maxima) & 70.0 \\
Cedro (Cedrella odorata) & 72.9 & Abiu (Pouteria caimito) & 72.9 \\
Tamburo (Vochysia spp.) & 80.0 & Amazon Grape (Pouromace cropifolia) \\
Laurel (Cordia alliodora) & 72.9 & Soursop (Annona muricata) & 68.3 \\
Bálsamo (Myroxilon balsamum) & 64.3 & Pineapple (Ananas comosus) \\
Caoba (Platymiscium pinnatum) & 31.4 & Papaya (Carica papaya) & 82.9 \\
Huambilla (Senna ruiziana caesalpiniaceae) & 52.9 & & \\
Batea (Cabralea canjerana) & 51.4 & & \\
Achotillo (Sloanea grandiflora) & 60.0 & & \\
GuapaYura (Otoba parvifolia) & 48.6 & & \\
\hline
\end{tabular}

On average, the farms studied had $9.27 \%$ of the 14 timber trees listed above. Specifically, more than $40 \%$ of the farms had more than ten different timber trees, and only $25 \%$ had five or less. Additionally, a wide variety of fruit trees was evident (e.g., lemon, abiu, custard apple, mandarin, orange, and papaya). On average, the farms had 8.4 of the 11 species considered.

Polyculture of a chakra has a logic in which there are elements clearly addressed to external markets and other crops with prevalent orientation to family consumption and altruistic exchange with friends and relatives. On the one hand, a main crop with a clear commercial purpose exists. As there are strong monetary needs in farmers' families, chakra's operation is generally governed by cocoa production. On the other hand, other crops that are primarily for family self-consumption are also present. Two are particularly relevant: banana and cassava. Cocoa alone was cropped on very few farms $(6.3 \%)$, which were generally small. On the remaining $93.7 \%$ of the farms, cocoa was combined with other crops. A typical farm had a mix of cocoa, banana and cassava. Banana was cropped on $91.4 \%$ of the farms. Cassava was also very important and was cropped on $87.1 \%$ of the farms. Corn $(40 \%)$, peanuts $(28.6 \%)$ and beans $(27.1 \%)$ were also cropped (Survey data).

Therefore, the chakra is a biological system composed of forest (often primary) and a rich mixture of crops acting complementary. For example, trees and other crops are essential for shade management, which is one of the basic features of cocoa cropping (see Figure 2). Additionally, as discussed below, a diverse biotic mass of trees is essential for the conservation of soil fertility.

Another key element of the chakra is the existence of very small-scale livestock rearing, particularly poultry farming, which has a strong biological rationality because it allows some foods that are not consumed by humans or exceed in some periods the needs of the family for consumption to be utilised.

"Here, we give them (chickens) cassava, the rest of chicha (Alcoholic beverage usually made from cassava), corn; here, we give them everything; when I go to work with the machete ... the crickets, the cockroaches, all the insects that we have on the island ... so live the chickens ... " 


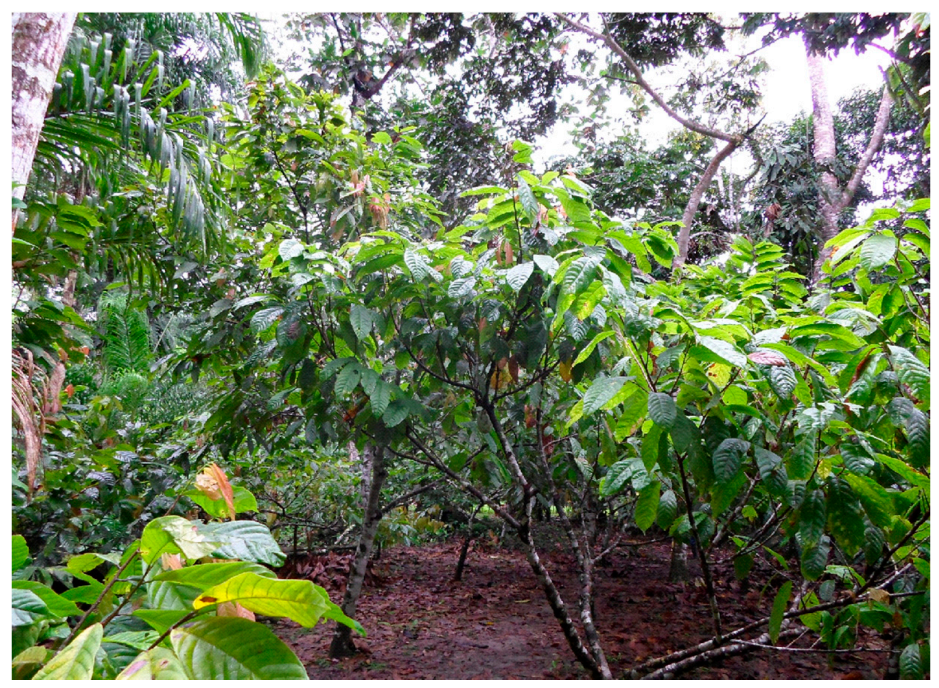

Figure 2. Cocoa trees, shade trees and the different heights of the chakra.

\subsection{Knowledge Subsystem}

As any other agroecological system, a chakra requires human intervention and cannot be maintained without human work. Thus, the chakra cannot be operated without the knowledge held by the family. That knowledge is additionally embodied in a set of practices that is the main basis of the farm management system.

\subsubsection{Maintenance of Soil Fertility}

Considering the characteristics of Amazonian land, e.g., the shallowness of the fertile soil layer and the deficiencies of certain nutrients, soil management is an essential element in the search of sustainable agricultural practices. Trees have three principal functions. Firstly, because an equatorial forest has a high capacity for the production of organic matter, trees provide much of the organic matter that breaks down and acts as an element of nutrient fixation in the soil. Thus, trees provide the closure of the material and nutrient cycles in the soil. Pruning rests and fallen leaves are also used for this purpose (see Figure 3). Secondly, trees capture inorganic nutrients from deeper soil layers and introduce them into the vegetation cycle, thus enriching superficial soil layers [30]. Finally, trees prevent erosion and the loss of the thin fertile soil layer.

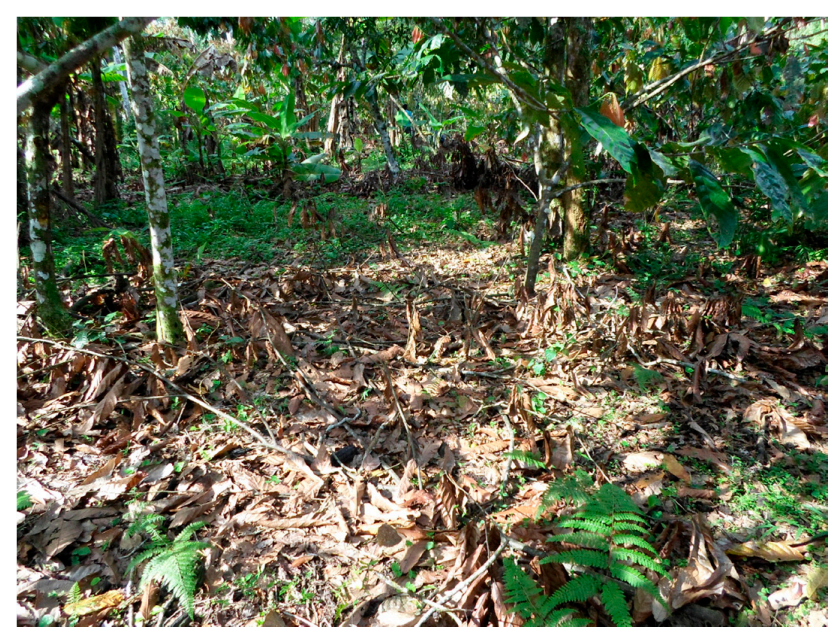

Figure 3. Maintenance of soil fertility based on nutrient recirculation. 
Therefore, the primary farm management tasks are centred on avoiding deforestation and implementing practices that maintain soil fertility; both of which are necessary to conserve the forest and the vegetation cover.

The relevance of this strategy is partially explained because other fertilisation options have been strongly rejected. For instance, not one of the farmers interviewed used any inorganic fertiliser during the previous year, and less than $25 \%$ said that they had applied organic fertiliser (Survey data), which indicated an especially strong general resistance to non-organic products.

\subsubsection{Maintenance of the Chakra and Pest Control}

An essential element in chakra management is vegetation control. As previously mentioned, because of the particular conditions of humidity and rainfall, the generation of organic matter is very high, which requires weed control to prevent, among other things, strong competition for nutrients that could damage the crops. Farmers use the criteria of "cleanness" to justify their practices. A failure to remove weeds is associated with a "dirty" farm and a social stigma. In fact, $49.2 \%$ of the work time is consumed by farm cleaning and weed removal. Given that the total work time on a chakra is $37.9 \mathrm{~h}$ per week, $19.5 \mathrm{~h}$ are committed to weed removal (Survey data).

On the other hand, many different pests and parasites inhabit the chakra. Pesticides are not used because many of the problems have no known effective treatment, so agricultural operations such as pruning or weed removal are the only potential control methods. The pruning of cocoa is thought to be advantageous for disease control, improving the production per tree. The proportion of pruning to the total work was $24.8 \%$, or an average of $9.4 \mathrm{~h}$ per week (Survey data).

\subsection{Value Subsystem}

Values are an essential element in the co-evolutionary operation of the chakra. Values can be understood as a set of background factors that contribute to decision-making processes, allowing one to choose among the different available alternatives. Because values always have a cultural basis, in this particular context, they should be related to the central elements of the Amazonian Kichwa community.

Values exist in Kichwa cosmology, and their expression exists in the form of myths and ceremonies. In a seminal work about Kichwa Amazonian Communities in Canelos, Whitten [86] showed that the equatorial rain forest was understood as a living entity populated by souls and spirits that were clustered around three key images: Amasanga, Nunkui and Tsunki. Those interrelated images supported the relationships among "plants, animals, insects, fish, humans, and the soul and spirits of the forest, air, soil and water" [86] (p. 840).

Amasanga is the spirit of the forest and is able take various masculine (Sacha Runa, JuriJuri... ) and feminine (Sacha Huarmi, AllpaSupai) forms. Thus, it is essential for understanding the interconnection among the different sets of elements (social, natural, spiritual, etc.) that affect life in the communities. This is one of the elements that explain why the majority of the chakras contain a certain proportion of forest, which is crucial for harmonising the relationships among their different components. Amasanga is related to the tendency to try to canalise natural flows and processes and not to deny them. Ultimately, the various forms of Amasanga as the spirit of the forest provide food to families and communities. This is related to the resistance to the use of some forms of agronomic intervention, which are subjectively considered as "too hard", for instance, inorganic fertiliser.

Nunkui is the spirit of the garden and handicraft. An inherent element of the chakra, Nunkui, has an evident aesthetical element, being associated with equilibrium and stability. Finally, Tsunki is understood as an ultimate source of life and is the spirit of the water, which also takes different masculine (Yaku Supai Runa) and feminine (Yaku Mama) forms. Therefore, from this perspective, water management is also an essential element.

Figure 4 shows the element of the garden (related to Nunkui) and the stabilising role of water (expression of Tsunki), in this case in a fish pond containing tilapia, showing how the values that 
inform the traditional Kichwa cosmology are essential in the construction and management practices of the chakra.

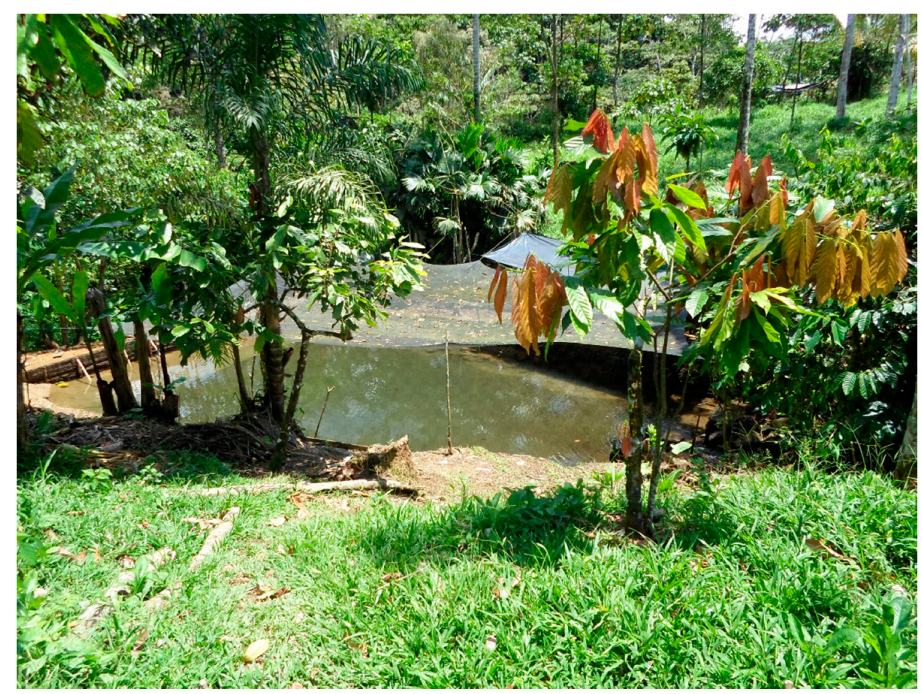

Figure 4. Aesthetic elements of the chakra.

\subsection{Subsystems of Organisation and Technology}

An investigation of the organisation of the chakra requires a careful analysis of the role of human work. As previously mentioned, the average workload of the chakra is $37.9 \mathrm{~h}$ per week. However, this is only an average value because the effective work time is highly variable and depends upon the monetary and food requirements of the family. In fact, the essential agronomic traits of the chakra can be maintained with a workload between 15 and $20 \mathrm{~h}$ per week (Table 3). If the work falls below this level, the chakra can be considered abandoned and will be reintegrated into the forest in a few years.

Table 3. Family working hours per week (\%).

\begin{tabular}{cc}
\hline Family Working Hours per Week & Percent \\
\hline Between 15 and $20 \mathrm{~h}$ & 21.4 \\
Between 20 and $40 \mathrm{~h}$ & 41.4 \\
Between 40 and $60 \mathrm{~h}$ & 18.6 \\
Between 60 and $80 \mathrm{~h}$ & 14.3 \\
More than $80 \mathrm{~h}$ & 4.3 \\
\hline
\end{tabular}

Family food requirements are an essential element that determines the effective workload of a chakra. Chakra families encompass the concept of the extended family (ayllu in Kichwa) that is smaller than the overall community (llacta) but larger than the nuclear family (huasi). Thus, it frequently includes ascendants and also sons and daughters, grandchildren and sometimes great-grandchildren. It is not exceptional for four generations to live together in a chakra family. In fact, in more than $70 \%$ of the cases, three generations shared the chakra space. The number of sons (5.3) is very high. Many young women remain in the family after having their first son. Thus, the presence of grandsons is common.

Someone is always responsible for cropping the chakra. This individual in this case is known as principal farmer. In fact, the majority of the workload is assumed by the principal farmer $(48.4 \%)$. The amount of family work - namely, that not performed by the principal farmer-is relevant, particularly for spouses. The contribution of sons and grandsons, albeit significant, barely reaches $25 \%$ (Survey data). However, the last indicator is sharply heterogeneous because family size tends to increase when the principal farmers is older. A chakra has to cover the food requirements of more people for a larger family. 
Table 4 shows the increase of family size with the age of the principal farmer. A strong relationship between the age of the principal farmer and the average workload per week is evident for that reason. The rise in the age of the principal farmer is associated with a larger family and thus with higher food and income requirements that cause an increase of the family workload.

Table 4. Family size and numbers of family hours per week according to the age of the principal farmer.

\begin{tabular}{ccccc}
\hline & $\begin{array}{c}\text { Family Size } \\
\text { (Number of } \\
\text { Members) }\end{array}$ & $\begin{array}{c}\text { Number of Family } \\
\text { Members Working on } \\
\text { the Chakra }\end{array}$ & $\begin{array}{c}\text { Family Hours Per } \\
\text { Week }\end{array}$ & $\begin{array}{c}\text { Main Farmer's } \\
\text { Hour Per Week }\end{array}$ \\
\hline Less than 40 years & 6.3 & 4.1 & 23.9 & 15.8 \\
Between 40 and 59 years & 9.9 & 4.5 & 41.4 & 19.9 \\
60 years or more & 18 & 4.1 & 45.9 & 17 \\
\hline
\end{tabular}

A test of the equality of means (Table 5) confirmed the previous results that family size and total family workload increased when the principal farmer is older. However, the increased workload is essentially explained by the greater involvement of the sons in cropping.

Table 5. Test of the mean equality according to the age of the principal farmer.

\begin{tabular}{llcccc}
\hline & \multicolumn{1}{c}{$\begin{array}{c}\text { Additional } \\
\text { Hypothesis }\end{array}$} & $t$-Statistic & $\begin{array}{c}p \text {-Value } \\
\text { (2-Tailed) }\end{array}$ & $\begin{array}{c}\text { Mean } \\
\text { Difference }\end{array}$ & $\begin{array}{c}\text { Std. Error } \\
\text { Difference }\end{array}$ \\
\hline Family size & $\begin{array}{l}\text { Equal variance not } \\
\text { assumed }\end{array}$ & 3438 & 0.001 & 5528 & 1608 \\
\hline $\begin{array}{l}\text { Family members } \\
\text { working in the chakra }\end{array}$ & $\begin{array}{l}\text { Equal variance } \\
\text { assumed }\end{array}$ & 2477 & 0.016 & 1.31691 & 0.53161 \\
\hline Family hours per week & $\begin{array}{l}\text { Equal variance not } \\
\text { assumed }\end{array}$ & 3854 & 0.000 & 18.04513 & 4.68211 \\
\hline $\begin{array}{l}\text { Principal farmer's hours } \\
\text { per week }\end{array}$ & $\begin{array}{l}\text { Equal variance } \\
\text { assumed }\end{array}$ & 1241 & 0.219 & 3.42060 & 2.75535 \\
\hline
\end{tabular}

From this point of view, the chakra is a typical peasant system in which agrarian production and the effective work charge are subordinated to the family's reproductive needs. Additionally, as in other peasant systems, some spouses, and especially sons, are employed in other sectors. The relevance of such activities and the increasing role of the formal education of children explain that only $35.7 \%$ of family members participate in the chakra workload. Therefore, the remaining $64.8 \%$ are underage for working or have other occupations. It is extraordinary to hire outside workers (survey data).

All of those elements are tied to a relatively simple technological system. Tools (essentially a machete) and equipment are relatively simple. Recently, chainsaws and brushcutters have been introduced. For this reason, the handling system is mainly based on human work and the solar energy cycle. Practically, no other sources of energy exist for exploitation, except the oil used for transport and for the operation of chainsaws and brush cutters.

In general, chakra's system allows the satisfaction of family food needs. Considering only crops (and, as a consequence, ignoring other minor food productions as tree fruits, small-scale livestock, aquaculture of tilapias and hunting and fishing activities in nearby rivers and forests), gross food production in energetic terms was 3.8 gigacalories per hectare and year. Thus, energetically speaking, chakra is above the standards of the subsistence farming systems [87]. Consequently, the average energetic production of the chakras is 2091 kilocalories per inhabitant per day. The majority of this production corresponds to banana and cassava, around $40 \%$ each. If some additional production were considered (such as fruits, livestock, etc.), the gross production could increase around $20 \%$. Therefore, food production of the chakra is enough for assuring subsistence of families of the principal farmers (survey data).

However, as a result of the relatively low agrarian prices, their average gross production in monetary terms was extremely low, only 2104 dollars per farm and year. Namely, chakra is inevitably 
associated to high levels of monetary poverty that, however, is not associated with a lack of food, but is related with other multiple shortages and deprivations. Therefore, the search of new sources of income is one of the main priorities of family farmers. In addition, the increase in the revenues is one of the major elements of transformation of the systems of farm management. For instance, chakra's cocoa is increasingly introduced in specific quality strands associated to the reception of premium prices [88]. In addition, families have progressively new sources of income outside farms, even though the situation is very different in the analysed communities. It was relatively frequent in Bajo Talag and Shandia that were relatively close to the city of Tena. These communities have developed some touristic facilities that were run under the form of community management. However, it was very rare in Canelos which is more isolated in territorial terms. In addition, they often perceive some public benefits as for instance, the bono de desarrollo humano (human development voucher) or, in some cases, some specific subsidies addressed to promote environmental conservation, such as programa socio-bosque (socio-forest program) [89]. In any case, the reality of the Amazonian Kichwa communities is characterised by high levels of monetary poverty.

\section{Discussion: Synthetic Considerations about the Chakra as Co-Evolutionary System}

Amazonia currently has different problems originated from the increasing pressure over its territory $[7,13]$. One of them is the expansion of the agrarian frontier that, in turn, is explained by the expansion of the processes of colonization and its own demographic growth of the Amazonian population [12,13]. In this context, chakras are agroecological systems particularly interesting from a strong sustainability perspective due to different reasons. Firstly, they are able to limit the territorial expansion of agriculture. Chakras are relatively small farms in the Ecuadorian Amazonian context (an average of 16.7 hectares). For instance, after the land reform of 1964 an important population coming from the highlands arrived to the EAR. Ecuadorian State recognized properties of 50 hectares to newly arrived colonists. Therefore, chakras size is decisively smaller. Moreover, an important share of chakras (around $40 \%$ ) is occupied by primary or secondary forest, promoting the coexistence of forest and farming. Additionally, chakras are basically polyculture systems, characterised by high levels of biodiversity, even inside the part of the farm assigned to agrarian production. In fact, the chakra is a typical agroforestry system and is thus quite different from the majority of existing agrarian systems, which are based on the cropping of specific varieties of very concrete plants. There are a large set of fruit and timber trees not only in the farms, but also in the cropped area. Such richness of vegetal species, in general, and trees, in particular, is an essential factor for avoiding erosion and maintaining soil fertility, one of the major vulnerabilities of the Amazonian ecosystems. Therefore, chakras are constructed in a way in which it does not seem appropriate to speak of deforestation. On the contrary, chakra system shows that in the Amazonian context agrarian exploitation and the maintenance of high levels of biodiversity are compatible.

For all those reasons, in the current context of dramatic transformations of the patterns of land use in the EAR, chakra system must be understood as essential element in any process of sustainable transition [26] For instance, there are increasing problems of soil depletion and erosion in many of the Amazonian lands used for raising cattle [4] In this context, chakras' experiences of reconversion of those lands have allowed both the rapid recovery of some environmental elements and their agrarian use.

“..., land that was previously used for paddocks is now used to plant cocoa or grass for livestock, and now we see that people who were previously ranchers, now live and work for cocoa ... (Restructuring) depends on the group you are considering. For a Kichwa is not difficult ..."

Nevertheless, the chakra cannot be only understood in ecological terms, being essential the interaction among ecological and social factors. In this sense, the chakra is a prominent example of biological and social co-evolution. There are many social aspects without whom chakras cannot be understood neither as agroecological nor as coevolutionary systems. For instance, Kichwa systems of knowledge and value play an essential role in this way of understanding agrarian production, the 
relationship between man and nature and the landscape. The knowledge system contains the content of the set of handling practices, which has proven to be particularly successful in sustaining a high level of biodiversity, erosion control, the preservation of soil fertility, maintenance of the chakra and pest control. Knowledge is embodied in abilities which are frequently implicit. The transmission to individuals who are not part of the community is sometimes difficult. In any case, this knowledge must not be understood as a closed complex of wisdom; on the contrary, it is continuously evolving.

The value subsystem reinforces traditional wisdom, being therefore a constant dialogue with knowledge subsystem. Consequently, chakras also have a normative content. Thus, they are understood not only as agrarian endeavours but also as gardens. Having a beautiful farm has an elevated social value because it is proof of a careful approach to nature, and a sign of commitment to raising children who are socialised to recognise the centrality of care. All those elements are associated with essential elements of the Kichwa cosmology, particularly with Nunkui. Additionally, chakras also have strong emotional characteristics because Kichwa conception of community includes not only humans but also animals, plants and even forest spirits, which are supposed to inhabit in the own chakra. For those reasons, the chakra has a meaning beyond any utilitarian approach. In some sense, it is, as any garden, an end in itself.

Such continuous dialogue between knowledge and values can explain the generation of a set of attitudes of refusing "hard" forms of agronomic intervention, as inorganic fertiliser for instance, as an example of what some authors call Sacred Ecologies [90]. However, there are at least another two reasons. Firstly, it is not profitable in economic terms. Yields of chakra systems are much reduced and the only way of having a minimal economic return is a strategy of zero monetary costs in which gross monetary income can be entirely considered as a family income. As result, there is no almost monetary expense. Labour basically come from family and inputs used are essentially free because they come from their own farm. In this sense, material cycles tend to be closed in which is a positive ecological feature. Therefore, there is no contradiction between embedded economic and ecological rationalities. Secondly, the rejection of hard forms of agronomic intervention is also explained by the deficiencies of the Ecuadorian State system of agrarian extension, which is not very receptive to new agroforestry techniques. The absence of an institution with an open agroforestry approach does not contribute to the generation of scientific and productive knowledge, which was territorially adapted. Thus, a lack of research of the essential elements of the chakra exists for subjects such as the compatibility of different plants, nutrient cycle management, optimal levels of livestock development or the best methods for avoiding plant proliferation. Nevertheless, Kichwa farmers and associations have been deeply involved in the development of organic fertilisers, which are used in $25 \%$ of the surveyed farms. However, their idea was to produce their own organic fertilisers in their own farms or, in any case, in farmers' cooperative. Therefore, they want to avoid any monetary cost and market dependency.

Another important social issue in the chakra's system was gender relations. The chakra is traditionally seen as an essentially female institution. As in other indigenous nationalities, a broad differentiation in gender labour roles exists in the Kichwa community. Traditionally, women have been focused on cultivation and men on hunting and gathering activities, but that does not mean that men did not have responsibility for the chakra. Whitten [68] reports that in the Kichwa community of Canelos women were in charge of the planting of cassava, potatoes and other root crops. The role of women in the cassava crop was particularly important and in the subsequent creation of the "chicha". This is an especially important social beverage because it is the basis of almost all festive and socialisation activities [91,92]. However, bananas and corn were mainly male responsibilities. Chakra organisation, as well as the indigenous communities themselves, is in a process of transformation from a gender perspective. Such changes are not homogeneous, affecting different indigenous communities in different forms and degree. There has been a redefinition of male and female roles. Masculinity has a tendency to be redefined because, instead of hunting, a relevant share of a man's contribution to the family's support has been working outside the agrarian context of the chakra. However, not all or even the majority of men have access to new sources of income, and often, such employment is temporary, 
discontinuous and precarious. In those cases, their relationship with the chakra is often strengthened. Consequently, the gendered division of labour has been redefined in such a way that the men have become the principal farmer on the chakra, and female empowerment has diminished. Such tension in the gendered division of labour explains the relative balance that exists in the gender of the principal farmer. Approximately $40 \%$ of the principal farmers are women, another $40 \%$ are men, and for the remaining $20 \%$, both members of the couple are equally involved (Survey data). A relevant but not generalised process of female empowerment thus exists.

However, socially speaking, the most important role of the chakras is their contribution to the food security of Kichwa families because they provide the basic food for family maintenance, and the house is also frequently located inside. Relations between chakra's farm management and family food provision explain that chakras are adapted to the changes in the domestic demand of food. Thus, when the principal farmer is older, families tend to be bigger, food demand is usually greater and, therefore, the number of family hours worked per week rise. In this sense, chakras operate as typical peasant systems in which the reserve of family labour is mobilised if it is necessary for broader strategies of family reproduction [93]. In the same line, the workload of spouses and sons are also used when family members can find jobs in other sectors. In addition, currently, education of children is socially highly valued and child labour is increasingly understood as a complement or even a form of socialization related with relevant normative elements.

In any case, chakra produce enough for feeding Kichwa families and communities, specifically 2091 calories per inhabitant per day. The chakra is associated with the generation of a relatively stable food supply and, thus with what is sure and with what does not fail. This food supply is also associated with a relatively stable, but absolutely insufficient monetary income of 2104 dollars per farm and per year (Survey data). Therefore, there are many external needs that cannot be satisfied by chakra's revenues. Outside work is not only more profitable, but an absolute necessity. However, it is socially constructed as more insecure, because it is perceived as out of communities' control.

Chakras' biodiversity is associated with the generation of diverse agrarian production (e.g., cocoa, bananas, cassava, fruits, etc.). As this production is largely addressed to family self-consumption, chakras' biodiversity is closely associated with the existence of varied, equilibrated and relatively stable family diets. Biodiversity (as for instance the variety of fruit trees, the existence of small-scale livestock or even activities of hunting in the neighbour forest) can be understood as sources of family health. Additionally, chakras also provide very reduced but relatively stable monetary income which are, at least partially apply in buying of food that are not available by systems of self-production or altruistic exchange. Hence, the specific characteristics of the chakra's biological subsystem are at the centre of the family strategies of family reproduction among the Kichwa. Thus, considering the high levels of social cohesion among the members of the different Kichwa communities, the own internal operation of the Amazonian Kichwa community cannot be understood without the chakra. It ensures housing and a positive environmental setting, according to Kichwa values. It is a productive construct that is, in many senses, exemplary from an environmental perspective. It also promotes the social reproduction of the extended families (ayllus) and, through mechanism of altruistic exchange when there are surplus, of the entire Amazonian indigenous communities (llacta).

Summarizing, the chakra can be understood as a co-evolutionary reality governed by a set of intense and proximate interactions. The biological subsystem is supported by continuous human work, by a combination of agrarian practices and an ensemble of traditional wisdom. In turn, the social reproduction of the Kichwa community depends on the generation of a food energy flow that is more or less constant. For this purpose, crops and livestock must be adapted to the environment. Such a set of interactions confers great stability on the overall system. Consequently, the chakra is a clear illustration of strong co-evolution [79]. Thus, it is supported by nearby interactions among crops, livestock, the resources needed for developing those activities and their environmental effects. Closeness of those interactions is an aspect increasingly infrequently found in contemporary food relationships [80]. All of these elements are particularly relevant in a context of dramatic changes in landscape and land use 
in the EAR, which are a consequence of the extension of other patterns of colonisation and specifically the result of the expansion of livestock activity [14]. In any case, chakra, as a (co)evolving system, is far from any steady state. Chakra is changing as result of increasing population, lower availability of lands, increasing food family requirements and higher possibilities of access to jobs and incomes outside. Such capacity for change and adaptation without generating substantially higher ecological impacts is central to understand its function in a context of dramatic changes in the EAR.

Environmental policies in Ecuador have frequently considered as desirable the restriction of the expansion of the agricultural frontier in the Amazonian region. However, a deeper insight in the existing agrarian systems shows that we should not reify the concept of the agrarian frontier. Therefore, while the colonist systems are characterised by an extensive land use with relevant environmental impacts, the chakra is a mixed concept with lower consumption of spaces, with higher biodiversity levels and with better control of erosion and losses of soil fertility. It could even be asserted that chakras increase the existing diversity, generating a new type of landscape with high environmental value, which coexists with primary and secondary forests. Under any circumstances, not all expansion of the agricultural frontier can equally be considered in socio-economic and environmental terms. Namely, it is not the same in social and environmental terms, the expansion of the agrarian frontier supported by colonists and livestock which have several environmental impacts, particularly in terms of erosion [4,14], than the territorial expansion of chakra's systems.

\section{Conclusions}

Chakras are specific agroforestry systems which cannot be understood without considering their high levels of ecological and social embeddedness. From an ecological point of view, chakras can be considered as an evolution of the humid Amazonian Forest. In fact, forest is still present in the majority of the farms and it represents more than $40 \%$ of their overall surface. From a social perspective, chakras are the result of the embodiment of a set of values, deeply inserted in the Kichwa worldview. Moreover, chakras are a prominent example of socio-ecological coevolution. Ecological and Social elements are characterised by closed interactions among them, having chakras their own processes of bio-social self-regulation. Such processes enhance the possibilities of adaptation of Kichwa communities to changing conditions. For instance, crop production and total working hours change according to the evolution of family needs. In this sense, chakras' average production is enough for assuring relevant levels of food sovereignty, respecting ancestral wisdom. Thus, they provide Kichwa families strategic food resources for confronting the dramatically changing socio-economic context of the Ecuadorian Amazonian Region. For all those reasons, the particular features of chakras can mitigate the impact of human population growth in Amazonia.

Acknowledgments: This study was supported by the next research projects: (1) Agrofood chains in the Amazonia, funded by Secretaría Nacional de Educación Superior, Ciencia, Tecnología e Innovación (Senescyt) of Ecuador; and (2) the annual internal grant 2016 promoted by the vice-presidency for research at Universidad del Pacífico (Lima, Perú).

Author Contributions: Daniel Coq-Huelva designed the overall research, designed questionnaires and in-depth interviews scripts, participated in the fieldwork and wrote the final article. Angie Higuchi made a first analysis of the information of the questionnaires. Rafaela Alfalla-Luque made a first analysis of the content of in-depth interviews. Ricardo Burgos Morán organized, monitored and directly participated in conducting in-depth interviews. Ruth Arias Gutierrez organized and monitored the fieldwork related with questionnaires.

Conflicts of Interest: The authors declare no conflict of interest.

\section{References}

1. Dirzo, R.; Raven, P.H. Global state of biodiversity and loss. Annu. Rev. Environ. Resour. 2003, 28, 137-167. [CrossRef]

2. Myers, N. The World's forests and their ecosystem services. In Nature's Services: Societal Dependence on Natural Ecosystem; Daily, G.C., Ed.; Island Press: Washington, DC, USA, 1997. 
3. Myers, N.; Mittermeier, R.A.; Mittermeier, C.G.; da Fonseca, G.A.B.; Kent, J. Biodiversity hotspots for conservation priorities. Nature 2000, 403, 853-858. [CrossRef] [PubMed]

4. Hecht, S.B. Environment, development and politics: capital accumulation and the livestock sector in Eastern Amazonia. World Dev. 1985, 13, 663-684. [CrossRef]

5. Rudel, T.K.; Bates, D.; Machinguiashi, R.A. Tropical forest transition? Agricultural change, out-migration, and secondary forests in the Ecuadorian Amazon. Ann. Assoc. Am. Geogr. 2002, 92, 87-102. [CrossRef]

6. Mena, C.F.; Bilsborrow, R.E.; McCain, M.E. Socioeconomic drivers of deforestation in Northern Ecuadorian Amazon. Environ. Manag. 2006, 36, 802-815. [CrossRef] [PubMed]

7. Baynard, C.W.; Ellis, J.M.; Davis, H. Roads, petroleum and accessibility of Eastern Ecuador. GeoJournal 2013, 78, 675-695. [CrossRef]

8. Fontaine, G. La globalización de la Amazonía: Una perspectiva andina. Iconos 2006, 25, 25-36. [CrossRef]

9. Finer, M.; Orta-Martinez, M. A second hydrocarbon boom threatens the Peruvian Amazon: Trends, projections, and policy implications. Environ. Res. Lett. 2010, 5. [CrossRef]

10. Sawyer, S. Crude Chronicles: Indigenous Politics, Multinational Oil, and Neoliberalism in Ecuador; Duke University Press: Durham, NC, USA, 2004.

11. Stetson, G. Oil politics and indigenous resistance in the Peruvian Amazon: The rhetoric of modernity against the reality of coloniality. J. Environ. Dev. 2012, 21, 76-97. [CrossRef]

12. Bretón, V. From agrarian reform to ethnodevelopment in the highlands of Ecuador. J. Agrar. Chang. 2008, 8, 583-617. [CrossRef]

13. Barbieri, A.F.; Carr, D.L.; Bilsborrow, R.E. Migration within the frontier: The second generation colonization in the Ecuadorian Amazon. Popul. Res. Policy Rev. 2009, 28, 291-320. [CrossRef] [PubMed]

14. Ríos, S.; Benítez, D.S.; Soria, R. Cadenas agroalimentarias territoriales. tensiones y aprendizajes desde el sector lácteo de la Amazonía Ecuatoriana. Lect. Econ. 2016, 84, 179-208. [CrossRef]

15. Bremmer, J.; Bilsborrow, R.; Feldacker, C.; Holt, F.L. Fertility beyond the frontier: Indigenous women, fertility, and reproductive practices in the Ecuadorian Amazon. Popul. Environ. 2009, 30, 93-113. [CrossRef]

16. McSweeny, K.; Arps, S. A demographic turnaround: The rapid growth of indigenous populations in Lowland Latin America. Lat. Am. Res. Rev. 2005, 40,3-29. [CrossRef]

17. Jokisch, B.D.; McSweeney, K. Assessing the potential of indigenous-run demographic health surveys: The 2005 shuar survey, Ecuador. Hum. Ecol. 2011, 39, 683-698. [CrossRef]

18. Siren, A.H. Natural resources in indigenous people's land in Amazonia: A tragedy of the commons? Int. J. Sustain. Dev. World Ecol. 2006, 13, 363-374. [CrossRef]

19. Gray, C.L.; Bilsborrow, R.E.; Bremmer, J.L.; Lu, F. Indigenous land use in the Ecuadorian Amazon. A cross-cultural and multilevel analysis. Hum. Ecol. 2008, 36, 97-109. [CrossRef]

20. Oldekop, J.A.; Bebbington, A.J.; Truelove, N.K.; Holmes, G.; Villamarín, S.; Preziosi, R.F. Environmental impacts and scarcity perception influence local institutions in Indigenous Amazonian Kichwa Communities. Hum. Ecol. 2012, 40, 101-115. [CrossRef]

21. Barbieri, A.F.; Bilsborrow, R.E.; Pan, W.A. Farm Households lifecycles and land use in the Ecuadorian Amazon. Popul. Environ. 2005, 27, 1-27. [CrossRef]

22. Sherman, M.; Ford, J.; Llanos-Cuentas, A.; Valdivia, M.J.; Busalleu, A. Vulnerability and adaptative capacity of community food systems in the Peruvian Amazon: A case study from Panaillo. Nat. Hazards 2015, 77, 2049-2079. [CrossRef]

23. Foucault, M. Power: The Essential Works of Michel Foucault; The New Press: New York, NY, USA, 2004.

24. Dean, M. Governmentality, Power and Rule in Modern Societies; Sage: London, UK, 2010.

25. Spivak, G.C. Can the subaltern speak? In Marxism and the Interpretation of Culture; Nelson, C., Grossberg, L., Eds.; University of Illinois Press: Urbana, IL, USA, 1988; pp. 271-313.

26. Whitten, N.E. Symbolic inversion, the topology of El Mestizaje, and the spaces of Las Razasin Ecuador. J. Lat. Am. Caribb. Anthropol. 2003, 8, 52-85. [CrossRef]

27. Schäpke, N.; Omann, I.; Wittmayer, J.M.; van Steenbergen, F.; Mock, M. Linking transitions to Sustainability: A study of the societal effects of transition management. Sustainability 2017, 9, 737. [CrossRef]

28. Alrøe, H.F.; Sautier, M.; Legun, K.; Whitehead, J.; Noe, E.; Moller, H.; Manhire, J. Performance versus values in sustainability transformation of food systems. Sustainability 2017, 9, 332. [CrossRef] 
29. Herrmann, T.M.; Torri, M.C. Changing forest conservation and management paradigms: Traditional ecological knowledge systems and sustainable forestry: Perspectives from Chile and India. Int. J. Sustain. Dev. World Ecol. 2009, 16, 392-403. [CrossRef]

30. Nair, P.K.R.; Buresh, R.J.; Mugendi, D.K.; Latt, C.R. Nutrient cycling in tropical agroforestry systems muths and science. In Agroforestry in Sustainable Agricultural Systems; Buck, L.E., Lassoie, J.P., Fernandes, E.C.M., Eds.; CRC Press: London, UK, 1999.

31. Schroth, G.; Harvey, C.A.; Vincent, G. Complex agroforest: Their structure, diversity and potential role in landscape conservation. In Agroforestry and Biodiversity Conservation in Tropical Landscapes; Schroth, G., da Fonseca, G.A.B., Harvey, C.A., Gascon, C., Vasconcelos, H.L., Izak, A.M.N., Eds.; Island Press: London, UK, 2004.

32. Hansmann, R.; Mieg, H.A.; Frischknecht, P. Principal sustainability components: Empirical analysis of synergies between the three pillars of sustainability. Int. J. Sustain. Dev. World Ecol. 2012, 19, 451-459. [CrossRef]

33. Faber, N.; Jorna, R.; Van Engelen, J.O. The sustainability of "sustainability"-A study into the conceptual foundations of the notion of "sustainability". J. Environ. Assess. Policy Manag. 2005, 7, 1-33. [CrossRef]

34. Bolis, I.; Morioka, S.N.; Sznelwar, L.I. When sustainable development risks losing its meaning. delimiting the concept with a comprehensive literature review and a conceptual model. J. Clean Prod. 2014, 83, 7-20. [CrossRef]

35. Georgescu-Roegen, N. The Entropy Law and the Economic Process; Harvard University Press: Cambridge, MA, USA, 1971.

36. Daly, H.E. Steady State Economics; Island Press: Washington, DC, USA, 1971.

37. Fischer-Kowalski, M. Society's metabolism. J. Ind. Ecol. 1998, 2, 61-78. [CrossRef]

38. Klöpffer, W. Life cycle assessment. Environ. Sci. Pollut. Res. 1997, 4, 223-228. [CrossRef] [PubMed]

39. Wackernagel, M.; Rees, W.E. Our Ecological Footprint: Reducing Human Impact on the Earth; New Society Publishers: Gabriola Island, BC, Canada, 1996.

40. Janze, D.H. When is it coevolution? Evolution 1980, 34, 611-612. [CrossRef] [PubMed]

41. Ehrlich, P.R.; Raven, P.H. Butterflies and plants: A study in coevolution. Evolution 1964, 18, 586-608. [CrossRef]

42. Norgaard, R.B. Sociosystem and ecosystem coevolution in the Amazon. J. Environ. Econ. Manag. 1981, 8, 238-254. [CrossRef]

43. Norgaard, R.B. Coevolutionary agricultural development. Econ. Dev. Cult. Chang. 1984, 32, 525-546. [CrossRef]

44. Norgaard, R.B. Development Betrayed: The End of Progress and a Coevolutionary Revisioning of the Future; Routledge: Abingdon, UK, 1994.

45. Woodgate, G.; Redclift, M. From sociology of nature to environmental sociology: Beyond social construction. Environ. Values 1998, 7, 4-24. [CrossRef]

46. Zimmerer, K.S. Rescaling irrigation in Latin America: The cultural images of political ecology of water resources. Cult. Geogr. 2000, 7, 150-175. [CrossRef]

47. Zimmerer, K.; Basset, T. Approaching political ecology: Society, nature and scale in human-environment studies. In Political Ecology: An Integrative Approach to Geography and Environment-Development Studies; Zimmerer, K., Basset, T., Eds.; Guilford Press: New York, NY, USA, 2003.

48. Turner, T. Shifting scales, lines and lives: The politics of conservation science and development in the Sahel. In Globalization and New Geographies of Conservation; Zimmerer, K., Ed.; Chicago University Press: Chicago, IL, USA, 2006.

49. Castree, N.; Braun, B. The construction of nature and the nature of construction: Analytical and political tools for building survivable futures. In Remaking Reality. Nature at the Millennium; Braun, B., Castree, N., Eds.; Routledge: London, UK, 1998.

50. Norgaard, R.B.; Sikor, T. The methodology and practice of agroecology. In Agroecology: The Scientific Basis of Alternative Agriculture; Altieri, M.A., Ed.; Westview Press: Boulder, CO, USA, 1995.

51. Kallis, G. Socio-environmental coevolution: Some ideas for an analytical approach. Int. J. Sustain. Dev. World Ecol. 2007, 14, 4-13. [CrossRef]

52. Diamond, J. Collapse: How Societies Choose to Fail or Succeed; Penguin: New York, NY, USA, 2005. 
53. Rammel, C.; Staudinger, M. Evolution, variability and sustainable development. Int. J. Sustain. Dev. World Ecol. 2002, 9, 301-313. [CrossRef]

54. Berkes, F. Understanding uncertainty and reducing vulnerability: Lessons from resilience thinking. Nat. Hazards 2007, 41, 283-295. [CrossRef]

55. Berkes, F.; Folke, C. Linking Social and Ecological Systems: Management Practices and Social Mechanisms for Building Resilience; Cambridge University Press: Cambridge, UK, 1998.

56. Toledo, V.; Barrera-Bassols, N. La Memoria Biocultural: La Importancia Ecológica de Las Sabidurías Tradicionales; Icaria: Barcelona, Spain, 2008.

57. Saifi, B.; Drake, L. A coevolutionary model for promoting agricultural sustainability. Ecol. Econ. 2008, 65, 24-34. [CrossRef]

58. Berkes, F.; Berkes, M. Ecological complexity, fuzzy logic and holism in indigenous knowledge. Futures 2010, 41, 6-12. [CrossRef]

59. Kallis, G.; Norgaard, R.B. Coevolutionary ecological economics. Ecol. Econ. 2010, 69, 690-699. [CrossRef]

60. Gual, M.A.; Norgaard, R.B. Bridging ecological and social systems coevolution: A review and proposal. Ecol. Econ. 2010, 69, 707-717. [CrossRef]

61. Kallis, G. Coevolution in water resource development: The vicious cycle of water supply and demand in Athens, Greece. Ecol. Econ. 2010, 69, 796-809. [CrossRef]

62. Sayre, N.F. Ecological and geographical scale: Parallels and potential for integration. Prog. Hum. Geogr. 2005, 29, 276-290. [CrossRef]

63. Uquillas, J.E. Colonization and spontaneous settlement in the Ecuadoran Amazon. In Frontier Expansion in Amazonia; Schmink, M., Wood, C.H., Eds.; University of Florida Press: Gainesville, FL, USA, 1981.

64. Haboub, M. Pueblos y Lenguas Indígenas de la Amazonía Ecuatoriana. Available online: http:/ / www.puce. edu.ec/oralidadmodernidad/docs/ART001_OM_2011.pdf (accessed on 15 August 2017).

65. Uzendovsky, M.A.; Calapucha-Tapuy, E.F. Ecology of the Spoken World: Amazonian Storytelling and the Shamanism among the Napo Runa; Illinois University Press: Chicago, IL, USA, 2012.

66. Albó, X. Suma qamaña = convivir bien. ¿Cómo Medirlo? In Vivir Bien: ¿Paradigma no Capitalista? Farah, I., Vasapollo, L., Eds.; CIDES-UMSA: La Paz, Bolivia, 2011.

67. Acosta, A. Buen Vivir Sumak Kawsay. Una oportunidad Para Imaginar Nuevos Mundos; AbyaYala: Quito, Ecuador, 2012.

68. Gudynas, E. Buen vivir: Today's tomorrow. Development 2011, 54, 441-447. [CrossRef]

69. Medina, J. Acerca del suma qamaña. In Vivir Bien: ¿Paradigma no Capitalista? Farah, I., Vasapollo, L., Eds.; CIDES-UMSA: La Paz, Bolivia, 2011.

70. Caria, S.; Domínguez, R. Ecuador's buen vivir: A new ideology for development. Lat. Am. Perspect. 2016, 43, 18-33. [CrossRef]

71. Hidalgo-Capitán, A.L.; Cubillos-Guevara, A.P. Seis debates abiertos sobre el sumak kawsay. Iconos 2013, 48, 25-40. [CrossRef]

72. Chaves, G.; Lara, R.; Moreno, M. Sarayaku: el Pueblo del Cenit, Identidad y Construcción étnica: Informe Antropológico-jurídico Sobre los Impactos Sociales y Culturales de la Presencia de la Compañia CGC en Sarayaku; Flacso: Quito, Ecuador, 2005.

73. Whitten, N.E.; Whitten, D.S. Puyo Runa: Imagery and Power in Modern Amazonia; University of Illinois: Urbana, IL, USA; Chicago, IL, USA, 2008.

74. Lansing, S.J. Complex adaptive systems. Annu. Rev. Anthropol. 2003, 32, 182-204. [CrossRef]

75. Chapura, M. Scale, causality, complexity and emergence: Rethinking scale's ontological significance. Trans. Inst. Br. Geogr. 2009, 34, 462-474. [CrossRef]

76. Erazo, J.S. Lanscapeidelologies, indigenous governance and land use change in the Ecuadorian Amazon, 1960-1992. Hum. Ecol. 2011, 39, 421-439. [CrossRef]

77. Morin, E. La Méthode. La Nature de la Nature; Editions du Seuil: Paris, France, 1977.

78. Berkes, F.; Colding, J.; Folke, C. Rediscovery of traditional ecological knowledge as adaptive management. Ecol. Appl. 2000, 10, 1251-1262. [CrossRef]

79. Winder, N.; McIntosh, B.S.; Jeffrey, P. The origin, diagnostic attributes and practical application of co-evolutionary theory. Ecol. Econ. 2005, 54, 347-361. [CrossRef]

80. Campbell, H. Breaking new ground in food regime theory: Corporate environmentalism, ecological feedbacks and the "food from somewhere" regime? Agric. Hum. Values 2009, 26, 309-319. [CrossRef] 
81. Kallis, G. When is coevolution? Ecol. Econ. 2007, 62, 1-6. [CrossRef]

82. Moreno-Peñaranda, R.; Kallis, G.A. Coevolutionary understanding of agrienvironmental change: A case-study of a rural community in Brazil. Ecol. Econ. 2010, 69, 770-778. [CrossRef]

83. Rios-Núñez, S.; Coq-Huelva, D.; García-Trujillo, R. The Spanish livestock model: A co-evolutionary analysis. Ecol. Econ. 2013, 93, 342-350. [CrossRef]

84. Creswell, J.W.; Piano Clark, V.L. Designing and Conducting Mixed Methods Research; Sage: Thousand Oaks, CA, USA, 2011.

85. Morgan, D.L. Integrating Qualitative and Quantitative Methods: A Pragmatic Approach; Sage: Thousand Oaks, CA, USA, 2014.

86. Uzendovsky, M.A. The Napo Runa of Amazonian Ecuador; University of Illinois Press: Urbana, IL, USA, 2005.

87. Fernández, J. La agricultura como fuente productora de energía. Agric. Soc. 1982, 24, 157-179.

88. Coq-Huelva, D.; Torres-Navarrete, B.; Bueno-Suárez, C. Indigenous worldviews and western conventions: Sumak Kawsay and cocoa production in Ecuadorian Amazonia. Agric. Hum. Values 2017, 3. [CrossRef]

89. Carrillo, P.E.; Jarrín, J.P. Efficient delivery of subsidies to the poor: Improving the design of a cash transfer program in Ecuador. J. Dev. Econ. 2009, 90, 276-284. [CrossRef]

90. Berkes, F. Sacred Ecologies; Routledge: New York, NY, USA, 2012.

91. Whitten, N.E. Ecological imagery and cultural adaptability: The Canelos Quichua of Eastern Ecuador. Am. Anthropol. 1978, 80, 836-859. [CrossRef]

92. Whitten, N.E. Sacha runa; Etnicidad y Adaptación de los Quichuas de la Amazonía Ecuatoriana; Abya-Yala: Quito, Ecuador, 1987.

93. Chayanov, A.V. The Theory of Peasant Economy; Manchester University Press: Manchester, UK, 1966.

(C) 2017 by the authors. Licensee MDPI, Basel, Switzerland. This article is an open access article distributed under the terms and conditions of the Creative Commons Attribution (CC BY) license (http:/ / creativecommons.org/licenses/by/4.0/). 